\title{
What Questions Are We Asking in the Contemporary Children's Literature Classroom?
}

\author{
Fazhuda Abdul Aziz \\ (Institute of Teacher Education Malaysia, Malaysia)
}

\section{Abstract}

doi:10.7575/aiac.alls.v.3n.1p.24

This case study of four B.Ed TESL Overseas Link Degree trainee teachers was undertaken with the intention of discovering what goes on in the classroom in terms of the trainee teachers' classroom interactions in relation to their questioning techniques and responses. This is looked at how much of thinking is being encouraged and how much of the learners' affective domain is being tapped through the teachers' questionings and responses during the Contemporary Children's Literature (CCL) lesson. Three methods of data collection; verbatim transcriptions of the video recorded observation of the respondents' lessons, interviews with the respondents and the respondents' reflections of the observed lesson were analysed and managed using NVivo 2.0, a qualitative data analysis software package. The findings show that the trainee teachers questions and responses in the CCL classroom falls under five categories; closed/display, inferential, open/referential, affective and other nonrelated questions and responses.

\section{Background}

The Newly Integrated Primary School Curriculum (KBSR) and the Newly Integrated Secondary School Curriculum (KBSM) were introduced in the Malaysian schools in 1989 due to a revamping of the national school curriculum (Foo \& Richards, 2004, p. 235). The syllabus for English Language for the primary and secondary schools was based on these new curricula respectively. By the turn of the new millennium, i.e., year 2000, the new syllabus for both primary and secondary schools were fully implemented (Foo \& Richards, 2004, p. 235).

In 1993, the Critical and Creative Thinking Skills (CCTS) were added into the curriculum whereby teachers are required to infuse CCTS across all subjects in both the primary and secondary schools. The infusion of CCTS is hoped to "sharpen learners' thinking abilities in 
order to enable them to make sound judgements" (Abdul Fatah, 1994 in Ramasamy, 2005, p. 67) as well as develop their thinking skills to be autonomous and independent learners in order to accomplish Vision 2020. Later, in the year 2000, the Literature Component in the English Language syllabus for secondary school was introduced into KBSM beginning with the Form One and Form Four levels. Over four years later in January 2004, the Contemporary Children's Literature was gradually introduced into the English language syllabus for primary school (KBSR) for the Level 2 pupils (Year 4-6) beginning with the Year 4.

There has been a revival of a literature-enriched curriculum in the current language teaching pedagogy. Certainly in Malaysia, we are embracing this revival with the move to infuse literary elements in the Malaysian Integrated Curriculum for both the Primary School (KBSR) and the Secondary School (KBSM). This is reflected through the implementation of the English Literature Component in the secondary school English Language syllabus in March 2000 and later the implementation of the Contemporary Children's Literature (CCL) programme in the primary school English Language syllabus in January 2004. This infusion of literary elements is clearly spelled out in one of the curriculums' objectives with regards to acquiring good reading habits to understand, enjoy and extract information from a variety of texts (Foo \& Richards, 2004, p. 235).

The Contemporary Children's Literature (CCL) programme is "introduced in primary schools nationwide in Malaysia as a follow-up to the structured reading programme which was implemented for the Year 1 and 2 pupils" (Mohamad Abu Bakar \& Rosli Talif, 2007, p. 22). The implementation of the CCL programme is to provide a bridge for the continuity of learning literature in the secondary school so that pupils will not face difficulty in learning literature at secondary school if they have some foundation at the primary level. The CCL was implemented gradually into the primary English Language syllabus beginning with the Year 4 learners in January 2004, Year 5 in June 2005 and the Year 6 in June 2006. Among the aims of the CCL are "to help learners improve their English through reading simple fiction, to provide a continuum for the literature component in secondary school and to create an enjoyable learning environment" (PPK, 2006). It is hoped that the use of literary materials such as short stories, excerpts from novels, fables, legends, and poems would not only encourage learners to read and to develop an interest in reading but would also provide learners with the opportunity of being exposed to models of the target language at its best (Kementerian Pendidikan Malaysia, 1989). 
According to the Curriculum Development Centre (1990) the presence of elements relevant to critical and creative thinking skills in literature justifies its implementation as the cognitive and affective domains are being stretched to the limit in the process. Thus, literature provides a most viable and conducive environment in developing and enhancing learners' critical and creative thinking skills. Some elements in appreciating literature, such as making discrimination and judgement allow learners to develop critical thinking skills.

\section{Statement of problem}

An important goal of education as stated by the NPE is to develop intellectually, emotionally, spiritually and physically balanced individuals who are capable of thinking for themselves. This can be achieved through the enhancement of thinking skills and the inculcation of emotional intelligence (EQ) and affective domain in lesson instructions. Both EQ and the affective domain of an individual relate to the emotional competence and well-being of a person in terms of intrapersonal and interpersonal competences. The intrapersonal competence deals with the deep understanding of oneself, whereas interpersonal competence deals with how one relates with others. The literature in classroom provides an avenue for this. According to Lawson (1993), both thinking and EQ are skills that "must be nurtured" (p.170). Lawson (1993, p.170) further suggests that "educational practice that nurtures the development of the thinking skills of the free mind (i.e. EQ) can be effective at all levels."

One of the objectives of the CCL syllabus is to enhance pupils' thinking skills (PPK, 2006). One of the ways to achieve this is through questions and responses that relates to the enhancement of critical thinking as well as the pupils' affective domain. This is achievable if teachers use one of the basic tools of thinking which is asking questions that allow learners to think critically. However, many of the questions asked by the teachers in the content classroom are of low level which relates to literal understanding and comprehension of a text and therefore does not promote and enhance thinking. Teachers do not pose many questions that go beyond the literal level and tap on the pupils' affective domain. In appreciating literature, it is not enough to just comprehend the text at a literal level. One must analyse, synthesise and evaluate the text using both the cognitive and affective domains of the brain.

It is important that this issue be addressed at an early stage before a trainee graduates to become a fully qualified teacher. This is crucial as once the teachers are being posted for their 
first teaching service, they would be fully equipped to infuse CCTS in both the ESL classroom as well as the literature content classroom. Therefore, it is essential that we explore the trainee teachers' classroom practice in terms of the infusion of CCTS in ESL and the literature lessons in order to gauge what goes on in the classroom.

\section{Research objectives and questions}

Based on the problem stated, this study was conducted with the focus to find out the types of questions used by trainee teachers in the CCL classroom, to examine the trainee teachers' classroom discourse in relation to the development of learners' thinking in the CCL classroom and to examine the trainee teachers' classroom discourse in relation to the development of the learners' affective domain in the CCL classroom. Subsequently, the following research questions were answered:

1. What are the types of questions used by teachers in the CCL classroom?

2. How are the trainee teachers' questions and responses encouraging learners' thinking in the CCL classroom?

3. How do the trainee teachers' questions and responses in the CCL classroom tap on the learners' affective domain?

\section{Literature review}

In the Malaysian education context, the teaching and learning of literature has been viewed as an essential means of improving learners' proficiency in the ESL classroom. This provides the rationale for implementing it as part of the English language curriculum. Although teaching language and literature may have their separate goals, using literature can help teach language by providing interest, content and variety. Using literary texts and materials in the language class can give benefits to language learners. Literary texts and materials also provide examples of language in use and can thus reinforce the learning of language.

Through literature lessons in the ESL classroom, we have one of the most viable and conducive environments in developing and enhancing students' critical and creative thinking skills as well as enhancing their emotional and affective domain. Hence, the involvement of the mental and emotional aspects in achieving high level critical and creative thinking profoundly justifies the teaching of critical and creative thinking skills through literature. Furthermore, it is truly assuring, as Lazar (1993) points out, that literary works have generally provided a wider scope to be explored in the field of the English language for both the 
learners and the teachers. This is further helped by the fact that the production of literary materials never ceases. The 'replenishing' of literary works in all genres seems unending and at times flowing.

Thinking and reasoning skills, according to Marzano (1998, p. 268), should not be "practiced in a vacuum [but] should be reinforced in the context of authentic tasks within their content areas." Similarly, Glaser (1984, in Chance, 1986) reasoned that thinking cannot be learned in an abstract way then simply applying it to situations one randomly encounters, but the ability to use a thinking skill in a particular context is the inevitable result of learning how to use it. Thus, in the context of the Malaysian primary school education, the CCL programme provides students an avenue to develop and enhance their thinking skills and affective domain in a particular context which they can apply to other contexts or situations that come along.

Much of the thinking done in formal education emphasizes on gathering information and understanding literal knowledge and comprehension of the information gathered. According to Ruggiero (1988), teaching students to think requires more than the mere possession of knowledge. He indicated that instruction should apply knowledge to problem situations within the academic discipline. In order to help nurture students' critical and creative thinking, teachers need to create and plan activities that go beyond mere recognition and understanding of information. Thus, the teachers' role could be described as one of structuring activities, assignments and lessons which incorporate all aspects of critical and creative thinking into the subjects which they teach. In attempting to do this, teachers need to build upon their students' innate abilities, interests, experience and background knowledge.

Teaching thinking is not an impossible task if the teacher knows how to go about it. It is important that thinking is taught constantly in order to help students improve their thinking and help them think for themselves and not merely to accept what other people have said without having done any evaluation. In teaching literature, it is important for students to realize that language can be very ambiguous. A teacher and a student may think that they are talking about the same thing when they read the same text, but they may have very different meanings attached.

In our rush to teach the cognitive process of thinking, we must not forget the students' emotional well-being. The development of the students' affective domain is as important as 
developing their thinking skills. Several researchers have agreed that the intellect and the emotions are inseparable (Barth, 1991; Leat, 1998; Lehtonen, 2005 and Patience, 2008) parts of an individual and therefore from a learning outcome perspective, it is necessary that classroom teaching and learning activities consider and engage the student affectively. These two skills must be balanced in students in order to develop them to be human beings who are personally and socially competent. Development of the affective domain involves awareness and insight into emotions rather than other mental functions. It is also a measure of an individuals' ability to understand and manage his or her emotions and interpersonal relationships.

At present, the emotional education of our students is left to develop on its own by chance. Schools pay little or no attention to developing the emotional intelligence of the students. More emphasis is put on developing the academic intelligence. However, EQ can be inculcated in the students through asking students questions that involve their affective domain. The students' emotional content will always have enormous power over students' attention and interest - either to focus or distract them from the lesson. According to Ediger (1997), positive quality emotions and feelings help students give their best potential in the classroom. This is because students who are aversive and think negatively will have more difficulty in reaching their potential than others. Additionally, they cannot concentrate for a long period of time. Therefore, he argues that teachers should stress on the affective domain that cannot be separated from the cognitive domain.

To effectively teach thinking, there are several tools that the teacher can employ in the lesson. The most important of all is through asking questions. According to Marzano (1993, p.154) the "most frequently used classroom method of enhancing thinking is questioning" and "in general, teachers ask far more questions than they are aware of." Asking questions is one of the main and oldest methods of teaching thinking. Edward de Bono (1994) asserts that “questions are a most useful language device (p.70) ...for 'directing attention' to a particular matter and asking the listener to recount what he or she 'sees' (p.71)." Questions are tools for thinking because questions make people think.

According to Carter (2000, p.4) "asking questions - the central part of the process - is the key to what makes you a critical thinker." Given the importance of questions in enhancing thinking, it has been "the focus of research attention in both the content classrooms and 
language classrooms for many years" (Nunan, 1990 in Kam-yin Wu, 1993, p.49). Studies conducted in the content classrooms look at the cognitive level of questions in relation to student achievement (Redfield \& Rousseau, 1981, Winne, 1979 in Kam-yin Wu, 1993). Research in the language classrooms examined questions as a means of "eliciting more or less linguistic output and involving students in interaction" (Brock, 1986, Long \& Sato, 1983; and White \& Lightbown, 1984 in Kam-yin Wu, 1993).

There is an intimate interrelation between knowledge and thinking as well as thinking and feelings. According to Leat (1993, p.499), "thinking is inextricably linked to feelings" and any attempt to develop them must be given due consideration in education. It is this balance between the cognitive and affective domains that makes one a good and skilled thinker. It is also this balance that we need to inculcate in ourselves as well as our students. According to Goleman (1995), people of high IQ, they flounder; people with moderate EQ, they do surprisingly well and those with a lack of EQ can sabotage their intellect and ruin career. Thus, enhancing and developing the affective domain and EQ of our students is essential for human development and nation building. We do not want to be consumers of other people's model but we also want to be inventors and tailor it to our needs, to be able to adopt and adapt. Thus, we should equip our students now, while they are still young and impressionable, in terms of their thinking skills and the development of their affective domain or EQ. Similarly, we should also equip our teachers with the pedagogical skills, thinking skills and EQ in order to build a nation that can achieve Vision 2020. This can be achieved through the teaching of literature, as literature reflects our lives, deals with real world issues and encompasses universal values that our students can learn and appreciate in order to make them humane.

\section{Methodology}

The purpose of this research is to analyze the questions posed by teachers and their responses in relation to the development of thinking skills and tapping on the learners' affective domain in the Contemporary Children's Literature classroom. Therefore, the design of this research is qualitative and descriptive in nature in the form of a case study of several trainee teachers in a particular context. 


\section{Respondents}

The respondents for this study were four B.Ed TESL (Primary) Overseas Link Degree trainee teachers who were at that moment on a 12-weeks teaching practice in a semi-urban singlesession primary school in the outskirts of Kuala Lumpur. In identifying the samples for this study, the purposive sampling method was employed. The trainee teachers were in their fourth year of the B.Ed TESL degree programme. Prior to the degree programme the trainee teachers studied Foundation in Institut Perguruan Bahasa-bahasa Antarabangsa (IPBA) for 18 months. The trainee teachers did their first year degree in the same institute before going abroad to one of IPBA's partner institution for the second and third years of the overseas link degree programme. The trainee teachers returned to IPBA for their fourth or final year of their degree study. There were two females and two male trainee teachers involved in this research.

\section{Instruments}

A classroom observation forms the core of this study. Non-participant direct observation was opted. For the purpose of triangulation, interviews with the respondents were also conducted. The respondents' reflections of the class observed were also collected in gathering the data for this research. The instruments used were:

1. Classroom Observation - Video-recording of the observed classes

2. Interview - semi-structured interview schedule

3. Reflection - structured reflection schedule

\section{Data analysis}

All the data collected were related to the observed lessons in the classroom. A verbatim transcription was done for the observation of the lessons on the video recording and the audio recording of the interview.

The verbatim transcriptions of the recorded lessons were analysed by looking at the teachers' classroom interactions namely their questions and responses in the classroom. The data was analysed and managed using a qualitative data analysis software package, NVivo 2.0. Based on the analysis, the respondents' questions and responses were categorized into several constructs and sub-constructs. A model of the types of questions and responses that were posed in all the respondents' classrooms was created (Appendix A). Data analysed from the observation transcriptions enabled the researcher to answer the first research question which 
relates to the types of questions used by trainee teachers in the CCL classroom. The interview transcriptions and respondents' reflections were analysed by looking at the reasons for the respondents' questions and responses in the classroom.

\section{Findings}

Based on the analysis, it was discovered that the questions that the respondents posed in the CCL classroom fall under the following five categories: closed or display questions, inferential questions, open or referential questions, affective questions and other questions which are unrelated to the study of the content of the lessons. Most of the questions that were posed fall under the closed/display category which relates to recall of information and details either from the text or from the learners' background knowledge. Thus, most of the questions posed fall under the lower order thought processes that require learners to merely recall and remember facts. Furthermore, the study also found out that the respondents did not really give much focus on responses that relate to learners' feelings.

\section{Closed/display questions}

The first category of questions relates to the closed/display questions which required learners to remember details or information which expects a small number of possible responses as its acceptable answer as well as questions that the teacher already knows the answers to. These questions are asked to prompt learners to display what they have already learnt. Based on the analysis it was found that there are three sub-categories that fall under the Closed/Display Questions construct. These sub-categories include asking learners to recall information and details, prompting or probing learners to answer, and eliciting short answers from the learners. Furthermore, the recall category can be further divided into recall of details or information based on their background knowledge which may not be related to the texts that they have studied in the past. It was also discovered that questions under this category largely refer to the text studied which means that answers to the questions can be found in the text.

\section{Inferential questions}

The second category of questions that was discovered during the data analysis is the inferential questions category. Interestingly, both teachers' questions and teachers' responses fall under this category. These types of questions and responses require learners to make inferences from the text. Questions and responses under this category are very much related to the comprehension of the text. One sub-category of questions under inferential questions 
construct refers to questions that stimulate thoughtful responses when learners infer from the text. This type of questions also requires some degree of thinking but still at a low level of thought process. Learners' responses could also be answers that the teacher already knows or answers that the teacher does not know but would like to explore. Another sub-category of inferential questions and responses relates to the teacher either asking for clarification from the learners or giving clarification to the learners regarding what is in the text studied. Either way, all of the respondents use this type of inferential question to help learners comprehend the text better. The other sub-category of this type of questions and responses deals with the understanding of language in terms of vocabulary and translation, whereby learners are required to give meaning to word or phrases that they encounter in the text.

\section{Open/referential questions}

Open/Referential questions refer to questions and responses that are open-ended and beyond the text to some extent. The text is the basis for the teacher to explore beyond it. Questions in this category do not have a right or wrong answer and require a bit of thinking on the learners' part. Questions posed and responses given in the CCL classroom relate to learners making predictions of what happened next based on the text read and those questions relating to the learners' lives or routine. To some extent, questions and responses under this category were able to develop learners' thinking and tap on their affective domains.

\section{Affective questions}

The affective category refers to both questions and responses that relate to the learners' feelings and emotions. It could also be responses that motivate learners to participate in the classroom more. The questions that fall under this category relate to the teachers making affirmations to students' answers and responses, and teachers' providing positive emotional responses like praises that taps on the learners' feelings and emotions, motivation, and empathy. They are also used by the teacher when she intends to show appreciation for learners' good behaviour.

\section{Other questions}

This last category of questions asked in the CCL classroom relates to any other questions that do not refer to the research objectives and purposes in terms of comprehension and appreciation of the literary text studied. Questions in this category relate to the management of the classroom, for example. 
Based on the analysis, closed/display questions and inferential questions are related to the text to some extent. While open/referential and affective questions are beyond the text, another interesting discovery is that affective category can fall under both questions and responses, while the other categories are mainly related to asking questions. Majority of the questions that were posed in the classroom fall under the closed/display category, while only some are related to the other categories. However, despite the fact that closed/display questions do not really develop high-order thinking skills, they have an important part to play. For the learners, they help them to remember or recall what they have learnt and comprehend the text. For the teachers, they help them to gauge what the learners already know and understand before moving on further to the next stage.

\section{Implications}

Based on the findings of the research, it was discovered that questions and responses are an undeniably practical and viable method of developing learners' thinking skills and emotional competence in the literature lessons in the ESL classroom. However, a major barrier would be the teachers' lack of knowledge in terms of the various taxonomies available that they can refer to and use to formulate different question-types that are able to develop and encourage thinking skills as well as develop and enhance learners' personal and emotional responses.

In answering the research questions, the evidence obtained from this particular study shows that to some extent the trainee teachers do incorporate elements of thinking and emotional responses in their CCL lessons. However, there is still a long way to go before full incorporation and integration of the thinking elements and affective becomes a part of ESL teaching among our Malaysian teachers. This can be achieved if teachers are fully aware of CCTS, the Socratic Questioning and EQ, and how to go about incorporating them in their lessons.

In terms of the types of questions and responses that trainee teachers employ in the CCL classroom that tap on the students' affective domain, they relate to gauging students' feelings and emotions regarding the topic under discussion, relating to the characters of the literature texts, and discussions on their opinions and decisions about certain issues related to the characters of the text that they are studying.

Many of the questions that were posed in all the four observed lessons fall under the closed/display category, while only some are related to the other categories; inferential, 
open/referential and affective. According to Ho (2005, p.305), the closed/display questions are purposeful in allowing teachers to "check on the students' comprehension of the passage" so that they "can get an idea of whether they had understood the reading passage before proceeding further." Furthermore, open-ended and closed questions are useful. Open-ended questions promote critical thinking, while closed questions can attract the attention. Both the open-ended and the closed questions are valid questions to be asked in the classroom. However, when posing these types of questions, learners may need guidance as they sift through possible answers. Therefore, teachers must use questions from all levels of thinking as this will help learners to develop higher levels of critical thinking as well as at the typical knowledge and comprehension level.

Furthermore, at the primary school level, these types of recall questions and responses are crucial in developing thinking skills gradually according to stages; as the lower-order questions allow learners to recall and recognise information they have already learnt, while the higher-order questions will allow the learners to develop their thinking and reasoning skills. The questions that relate to the learners' affective domain and emotional responses will develop and enhance learners' emotional competence, which in turn develop the learners' soft skills.

\section{Recommendations}

Based on her experiences of being in schools, the researcher believes that most teachers are not aware that they actually do not ask many higher order thinking questions. They are also not aware that they need to infuse in their lesson the inculcation of thinking and EQ. Furthermore, many teachers are not aware that they need to focus on their questions and responses that involve the affective domain of the students.

Thus, one of the suggestions that the researcher wishes to make is to have some kind of training either at pre-service level or in-service level regarding the methodology of infusing thinking skills in lessons. Apart from that, some form of training in how to think for themselves can also be included in the training of in-service teachers and pre-service teachers. This is to equip them with the skills that they can use for themselves in making decisions and solving problem, so that they are aware of it and would be able to teach thinking skills and pass down to the learners their knowledge of how to think using the proper thinking tools that they have learned. 
With regard to this, perhaps throughout their training, teacher trainees need to be made more aware of the importance and value of thinking skills questions and responses as well as various ways of asking questions. This can be through modelling on the use of various questioning taxonomies and thinking skills by teacher educators who teach the trainees. Through such modelling, it should help the trainees get used to how they can incorporate thinking skills questions and responses during the teaching and learning process. In addition to that, teachers need to be exposed to the latest trends in teaching and education so that they are always informed. This also helps them to develop themselves professionally.

In addition, further research could be carried out on a wider sample of lesson observations. There are two ways of going about this. One is to observe the same teacher throughout several lessons of different nature (reading, writing, speaking, listening, grammar and literature) and some kind of compare and contrast analysis can be made based on the data gathered. An analysis on the teacher's consistency of infusing thinking and the enhancement of the learners' affective domain can also be made. Another way is to observe several teachers in maybe the same school or different schools, and some kind of comparison can be made in terms of the thinking questions and the inculcation of EQ in their lessons.

Finally, another suggestion for further research in the area of classroom interaction and discourse is to look at non-verbal interaction between learners and teachers, and see if there is any relationship between the non-verbal cues with the promotion and encouragement of learners' thinking skills and emotional competence or affective domain.

\section{Conclusion}

This study has presented the extent of using different question-types and responses which promote and encourage thinking skills and tap on the students' affective domain in the contemporary children's literature lesson in the primary school. The teaching of thinking skills and emotional competence need not be done discretely. Through the literature lessons, ESL teachers can inculcate thinking skills and develop emotional competence in their learners. Obviously, using questions and responses that involve higher level of thought processes can be the initial step toward achieving that goal as it is a simple but effective strategy. 


\section{References}

Barth, B. M. (1991). From Practice to Theory: Improving the Thinking Process, in Maclure, S. \& Davies, P. Learning to Think: Thinking to Learn, The proceedings of the 1989 OECD Conference Organized by the Centre for Educational Research and Innovation, Pergamon Press.

Carter, C. (2000). Keys to Thinking and Learning: Creating Options and Opportunities, New York: Prentice Hall Inc.

Curriculum Development Centre (1990). Pukal Latihan KBSM, Kuala Lumpur: MEM.

Chance, P. (1986). Thinking in the Classroom: A Survey of Programs. Columbia University, New York: Teachers College Press.

PPK (2006). Contemporary Children's Literature Programme for the Primary School, Unpublished PowerPoint Slides, Pusat Perkembangan Kurikulum, Kementerian Pendidikan Malaysia.

De Bono, E. (1994). Parallel Thinking: From Socratic to de Bono Thinking. London: McQuaig Group Inc.

Debbie Guan Eng Ho (2005). Why Do Teachers Ask the Questions they Ask? RELC Journal 36 (3), pp.297310. Retrieved on November 26, 2007 fromhttp://rel.sagepub.com/content/36/3/297.refs.html.

Ediger, M. (1997). Affective objectives in the science curriculum (Clearinghouse No. SE060514) Montgomery, AL: Auburn University at Montgomery, School of Education (ERIC Document Reproduction Service No. ED412070).

Foo, B. \& Richards, C. (2004). English in Malaysia. RELC Journal, 35 (2), 229-240.

Goleman, D. (1995). Emotional Intelligence: Why it can matter more than IQ? USA: Bantam Books.

Kam-yin Wu. (1993). Classroom Interaction and Teacher Questions Revisited. RELC Journal, 24 (2), 49-68.

Lawson, A.E. (1993). At What Levels of Education is the Teaching of Thinking Effective? Theory into Practice, $32(3), 170-178$.

Lazar, G. (1993) Literature and Language Teaching: A Guide for Teachers and Trainers, Cambridge: Cambridge University Press.

Leat, D.J.K. (1993). Competence, Teaching, Thinking and Feeling. Oxford Review of Education, 19 (4), 499510.

Lehtonen, M; Page, T and Thorsteinssen, G. (2005) Emotionality considerations in virtualreality and simulations based learning. IADIS International Conference on Cognition and Exploratory Learning in Digital Age (CELDA 2005), pp. 26-36.

Marzano, R.J. (1993). How Classroom Teachers Approach the Teaching of Thinking. Theory into Practice, 32 (3), 154-160.

Marzano, R.J. (1998). What are the general skills of Thinking and Reasoning and how do you teach them? Clearinghouse 71(5), 268-279.

Mohd Abu Bakar \& Rosli Talif (2007) Children's Literature: Practice in the Primary Classroom, in Rosli Talif, Jariah Mohd. Jan \& Malachi Edwin Vethamani (Eds.) Understanding Children's Literature (pp.22-31), SASBADI-MELTA ELT SERIES, Sasbadi Sdn. Bhd.

Patience, A. (2008) The Art of Loving in the Classroom: A Defence of Affective Pedagogy. Australian Journal of Teacher Education, Vol. 33 (2), 55-67.

Ruggiero, V.R. (1988). Teaching Thinking across the Curriculum, New York: Harper \& Row Publisher.

Sukatan Pelajaran Sekolah Menengah Bahasa Inggeris (1989). Kementerian Pendidikan Malaysia.

Ramasamy, V. (2005). ESL Teachers' Perception and Knowledge in the Teaching of Critical and Creative Thinking Skills, in Prosiding Seminar Penyelidikan dan Penilaian MPTAR 2005, Institut Perguruan Tun Abdul Razak, Sarawak (7-8 September). 


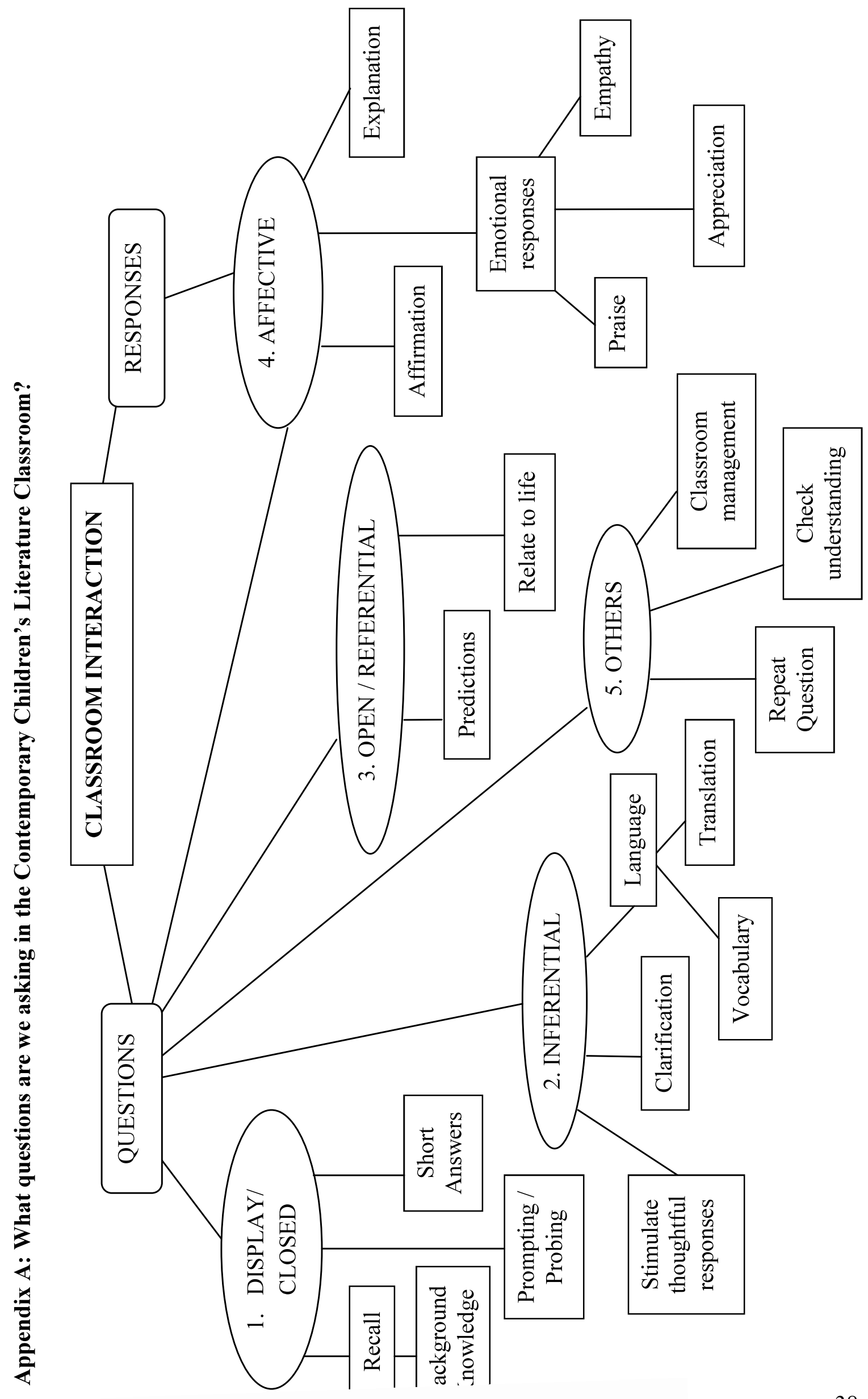

